\title{
Site- and time-specific early weed control is able to reduce herbicide use in maize - a case study
}

\author{
Nebojša Nikolić, ${ }^{1}$ Davide Rizzo, ${ }^{2,3}$ Elisa Marraccini, ${ }^{2}$ Alicia Ayerdi Gotor, ${ }^{4}$ Pietro Mattivi, ${ }^{5}$ \\ Pierre Saulet, ${ }^{6}$ Antonio Persichetti, ${ }^{7}$ Roberta Masin ${ }^{1}$ \\ ${ }^{1}$ Department of Agronomy, Food, Natural resources, Animals and Environment - DAFNAE, University of \\ Padova, Legnaro (PD), Italy; ${ }^{2}$ InTerACT (UP 2018.C102), UniLaSalle, Beauvais, France; ${ }^{3}$ Agricultural \\ Machinery and New Technologies, UniLaSalle, Beauvais, France; ${ }^{4}$ AGHYLE (UP 2018.C101), UniLaSalle, \\ Beauvais, France; ${ }^{5}$ Department of Civil, Chemical, Environmental, and Materials Engineering (DICAM), \\ University of Bologna, Bologna, Italy; ${ }^{6}$ Geolab, UniLaSalle, Beauvais, France; ${ }^{7}$ Archetipo s.r.l., Padova, \\ Italy
}

\section{Highlights}

- Efficacy of UAVs and emergence predictive models for weed control have been confirmed.

- Combination of time-specific and site-specific weed control provides optimal results.

- Use of timely prescription maps can substantially reduce herbicide use.

\begin{abstract}
Remote sensing using unmanned aerial vehicles (UAVs) for weed detection is a valuable asset in agriculture and is vastly used for site-specific weed control. Alongside site-specific methods, time-specific weed control is another critical aspect of precision weed control where, by using different models, it is possible to determine the time of weed species emergence. This study combined site-specific and time-specific weed control methods to explore their collective benefits for precision weed control. Using the AlertInf model, a weed emergence prediction model, the cumulative emergence of Sorghum halepense was calculated, following the selection of the best date for the UAV survey when the emergence was predicted to be at $96 \%$. The survey was executed using a UAV with visible range sensors, resulting in an orthophoto with a resolution of $3 \mathrm{~cm}$, allowing for good weed detection. The orthophoto was post-processed using two separate methods: an
\end{abstract}

Correspondence: Nebojša Nikolić, Department of Agronomy, Food, Natural resources, Animals and Environment (DAFNAE), University of Padova, viale dell'Università 16, 35020 Legnaro (PD), Italy.

E-mail: nebojsa.nikolic@phd.unipd.it

Key words: Precision weed control; remote sensing; predicting weed emergence; Sorghum halepense; maize.

Received for publication: 23 November 2020.

Revision received: 18 February 2021.

Accepted for publication: 19 February 2021.

(C) Copyright: the Author(s), 2021

Licensee PAGEPress, Italy

Italian Journal of Agronomy 2021; $16: 1780$

doi:10.4081/ija.2021.1780

This article is distributed under the terms of the Creative Commons Attribution Noncommercial License (by-nc 4.0) which permits any noncommercial use, distribution, and reproduction in any medium, provided the original author(s) and source are credited. artificial neural network (ANN) and the visible atmospherically resistant index (VARI) to discriminate between the weeds, the crop, and the soil. Finally, a model was applied for the creation of prescription maps with different cell sizes $\left(0.25 \mathrm{~m}^{2}, 2 \mathrm{~m}^{2}\right.$, and 3 $\mathrm{m}^{2}$ ) and with three different decision-making thresholds based on pixels identified as weeds $(>1 \%,>5 \%$, and $>10 \%)$. Additionally, the potential savings in herbicide use were assessed using two herbicides (Equip and Titus Mais Extra) as examples. The results show that both classification methods have a high overall accuracy of $98.6 \%$ for ANN and $98.1 \%$ for VARI, with the ANN having much better results concerning user/producer accuracy and Cohen's Kappa value ( $k=83.7 \mathrm{ANN}$ and $\mathrm{k}=72 \mathrm{VARI})$. The reduction percentage of the area to be sprayed ranged from $65.29 \%$ to $93.35 \%$ using VARI and from $42.43 \%$ to $87.82 \%$ using ANN. The potential reduction in herbicide use was found to be dependent on the area. For the Equip herbicide, this reduction ranged from 1.32 $\mathrm{L} /$ ha to $0.28 \mathrm{~L} /$ ha for the ANN; with VARI the reduction in the amounts used ranged from $0.80 \mathrm{~L} /$ ha to $0.15 \mathrm{~L} / \mathrm{ha}$. Meanwhile, for Titus Mais Extra herbicide, the reduction ranged from $46.06 \mathrm{~g} / \mathrm{ha}$ to $8.19 \mathrm{~g} / \mathrm{ha}$ in amounts used with the ANN; with VARI the amount reduction ranged from $27.77 \mathrm{~g} / \mathrm{ha}$ to $5.32 \mathrm{~g} / \mathrm{ha}$. These preliminary results indicate that combining site-specific and timespecific weed control might significantly reduce herbicide use with direct benefits for the environment and on-farm variable costs. Further field studies are needed for the validation of these results.

\section{Introduction}

Since its early beginnings, agriculture has constantly been changing and evolving, and the same trend continues to this day (Thrall et al., 2010). The human population has been cultivating plants throughout the ages, always searching for an economical and environmentally sustainable way to produce. For this purpose, different tools, equipment, and crop management practices have been created (Lobley and Potter, 2004; Gaillard, 2005; Paul and Nehring, 2005; Ricroch et al., 2014). Weeds, the unwanted plants that spontaneously emerge alongside crops, are one of the biggest constraints to crop production. Because of their biology and evo- 
lutionary path, they are more competitive than traditional crops, and therefore, they have a detrimental effect on crop yield (Radosevich et al., 2007; Holt, 2013; Lingenfelter and Hartwig, 2013). Weeds can cause serious losses by competing for natural resources but can also serve as potential hosts for various harmful organisms (Radosevich et al., 2007; Zimdahl, 2007; Cerrudo et al., 2012). In some cases, the percentage of yield loss caused by weeds can reach up to $84 \%$ (Imoloame and Omolaiye, 2017). Because the negative economic impact is measured in billions per year (Soltani et al., 2016), it is not surprising that significant effort has been placed into finding the best way to control these unwanted plants. Today, the measures used for weed control can mostly be grouped into two categories. Mechanical control, which involves the use of different tools and machines to remove and/or destroy weeds mechanically; and chemical control, which involves the use of different chemical formulations (herbicides), with the same aim (Arriaga et al., 2017; Peruzzi et al., 2017; Zimdahl, 2018). Other important weeds controlling techniques also include agronomic, physical, and cultural weed control. It is important to mention crop rotation and row spacing for agronomic techniques, while physical methods may include using the heat for weed control, such as using the flames or steam (Astatkie et al., 2007). Finally, cultural methods involve selecting the right variety, cultivar, or hybrid that can compete with plants and maybe even help the weed suppression, for example growing faster and creating the canopy that can shade the weeds (Melander et al., 2005). Although mechanical agronomic, physical and cultural weeding measures can be very efficient, they are not as effective as chemical weed control methods and should be used as a part of a holistic approach (Mohler, 1996; Weis et al., 2008). Furthermore, mechanical measures tend to be reduced or completely removed from newer production management systems, such as conservation agriculture, due to negative impacts such as soil compaction and disturbance. In addition, these operations may raise the production costs (e.g. machine maintenance, fuel) and can also lengthen the times of agricultural production, considering different tillage operations that are necessary for the soil preparation before sowing (Raghavan et al., 1990; Idowu and Angadi, 2013; FAO, 2014; Arriaga et al., 2017; Hussain et al., 2018). Therefore, chemical control methods have become the dominant technique for weed control, and in cases like conservation agriculture, it is one of the few effective means of weed control. The above means that the use of herbicides is always on the rise and has been on an upward trend since their introduction (FAO, 2014; Vats, 2015; Zimdahl, 2018). However, the use of herbicides has several negative effects on the environment brought on by leaching into soil and groundwater (Tiktak et al., 2004; Gimsing et al., 2019). This potentially leads to soil and water contamination, putting wildlife biodiversity at risk, and it can also be harmful to humans (Morales et al., 2013; Hasenbein et al., 2017; Gupta, 2018; Beasley, 2020). Herbicides can also enter the food chain via residues found on food and may have serious adverse implications (Morales et al., 2013; European Food Safety Authority, 2018). Today, the process of creating new herbicides is very slow due to the strict protocols imposed by the international organization's legislations such as FAO/WHO (FAO/WHO, 2016a, $2016 \mathrm{~b}$ ), and by national and supranational laws regulating production and the use of pesticides, e.g., European Parliament (2009); in order to reduce the negative effects that future herbicides may have (Lyon et al., 1996; Kudsk and Streibig, 2003). However, this harms traditional herbicide application due to the development of weed resistance to herbicides currently in use (Heap and LeBaron, 2001; Holt, 2013; Sherwani et al., 2015). All things considered, the use of herbicides in agriculture needs to be reshaped to guarantee their effectiveness and the stability of agricultural production and reduce environmental impact. One of the possible solutions to this problem could be the implementation of precision agriculture, which could enable the reduction of herbicides by applying them only where and when needed, thanks to the technological progress and innovative tools available for weed detection (Lyon et al., 1996; Zarco-Tejada et al., 2014). Current limitations to the use of precision weed control in the field are the identification of weeds and the associated decision support systems. However, among precision farming adopters, Ayerdi Gotor and colleagues (Ayerdi Gotor et al., 2020) have demonstrated that there is still poor use of these techniques for weeding. Given that weeds do not appear uniformly in space nor in time (Radosevich et al., 2007; Zimdahl, 2007; Martín et al., 2015; Santín-Montanyá et al., 2015), it is important to address this issue from both the spatial and temporal points of view (Forcella et al., 2000; Gerhards, 2013). Mapping the weeds in space has never been easy (Hanzlik and Gerowitt, 2016), but the development of unmanned aerial vehicles (UAVs) simplifies this task (Herwitz et al., 2004; Giacomo and David, 2017). For this purpose, some additional aspects could be exploited, such as the 3D model (Digital Surface Model), where the different heights of weeds and crops are used to discriminate between them (Stroppiana et al., 2018). In fact, some studies worldwide have started implementing UAVs for weed mapping as a part of precision agriculture, with auspicious results (López-Granados, 2011; Ballesteros et al., 2014; Hassanein and El-Sheimy, 2018; Huang et al., 2018; Lambert et al., 2018; Maes and Steppe, 2019). Depending on the flight altitude and the sensors used, UAVs can provide images with a resolution of a few centimetres or less than a centimetre, allowing for useful weed classification (TorresSánchez et al., 2013; Koot, 2014; Bareth et al., 2015; Candiago et al., 2015; Pérez-Ortiz et al., 2015). Moreover, images obtained in this way can serve as a basis for further analysis of spatial weed distribution (Borra-Serrano et al., 2015; Pérez-Ortiz et al., 2016). Weed emergence models have already been developed (Myers et al., 2004; Colbach et al., 2007; Dorado et al., 2009), to identify correct time for an effective weed control. The introduction of such models in decision support programs can reduce herbicide use and weed control costs when compared with standard management practices (Forcella et al., 2000). These models provide the percentage of cumulated emergence reached every day by weed species, and this information can be used to select the best timing for mechanical or chemical weed control methods to achieve maximum efficacy. One of these models, named 'AlertInf' was developed in Italy by Masin and colleagues (Masin et al., 2010). It uses the hydrothermal time concept (Bradford, 2002), in which the combination of soil temperature and soil water potential is the main factor driving germination (Masin et al., 2010, 2012, 2014).

To our knowledge, no study (or very few studies) in the scientific literature so far have addressed the combination of spatial and temporal weed detection. This study aims to bridge this gap and investigate the possible benefits of combining spatial and temporal approaches for precision weed control. In this experiment, UAVs were used to map the weeds present in a field, which were later identified with the help of spatial analysis software within a geographic information system (GIS). Afterward, based on the weed location results, prescription maps were created to support site-specific weed control. The main novelty of our approach was to use the AlertInf model to predict the cumulative emergence of weed species present in the field, providing time-specific weed control, thereby allowing us to define the best flight date to map the weeds. Eventually, the possible reduction of herbicide use was assessed by implementing and combining site-specific and time-specific weed control techniques. 


\section{Materials and methods}

\section{Study site}

The experiment was conducted at the experimental farm 'Lucio Toniolo' of the University of Padova at Pozzoveggiani locality, within the province of Padova in the Veneto region (northeastern Italy). The field morphology is flat, and the soil is classified as Fluvic Cambisol (FAO, 2006). The local climate is subhumid with an average temperature of $12{ }^{\circ} \mathrm{C}$ and $800-850 \mathrm{~mm}$ of rainfall, mostly during the autumn and spring months, based on the Regional Agency for Environmental Protection (ARPA) data. In this field, a hybrid of maize (DKC 5530) was sown on the $7^{\text {th }}$ of June 2019 with $75 \mathrm{~cm}$ interrow and $15 \mathrm{~cm}$ in-row spacing, while the previous culture was soybean Pioneer hybrid PR92M22, harvested on $11^{\text {th }}$ of October 2018. This late sowing date was due to unfavourable meteorological conditions during the late spring/early summer period. Prior to sowing, different tillage operations, commonly employed for soil preparations, were performed. On the $9^{\text {th }}$ of January 2019, weeding was performed using a grubber, on the $26^{\text {th }}$ of February $2019,53 \mathrm{~kg} \mathrm{~N} /$ ha was applied as manure, corresponding to $36 \mathrm{Mg} /$ ha of raw manure, on the $4^{\text {th }}$ of March 2019, false sowing was executed using the rotary harrow, on the $4^{\text {th }}$ of June 2019 shredding was implemented using a tiller, and on the $5^{\text {th }}$ of June 2019, a rotary harrow was used.

\section{Unmanned aerial vehicles survey}

The flight was performed with the Matrice $100 \mathrm{UAV}$, coupled with DJI X3 and DJI X5 visible sensors (DJI Sciences and Technologies Ltd., Shenzhen, China), on the $19^{\text {th }}$ of June 2019 when maize was at $10-11 \mathrm{BBCH}$ stage. The flight was executed at the height of $35 \mathrm{~m}$ from the ground over an area of 1 ha, providing an orthophoto with a resolution of $3 \mathrm{~cm}$. The orthomosaic was created with Pix4D software using the projected coordinate system of the Gauss Boaga Monte Mario Italy Zone 1 (EPSG:3003). The result was an accurate orthophoto allowing a relatively easy distinction between weed species and the surrounding elements (Figure 1).

\section{Weed classification methodologies}

Two different approaches were tested for weed classification: an artificial neural network (ANN) (OpenCV) using the SAGA GIS open-source software (version 7.6.2), and the visible atmospherically resistant index (VARI) using ArcGIS Pro software (version 2.2.0 ESRI - Environmental Systems Research Institute, Redlands, CA, USA).

The OpenCV algorithm operates by performing a backpropagation, one of the most widely used methods for training artificial neural networks for various purposes (Sözen et al., 2004; Murat and Ceylan, 2006; Elmolla et al., 2010; Turan et al., 2011). Backpropagation is an iterative process that consists of making a backward pass after each forward pass through the network while making the relevant adjustments to the model's parameters, namely weights and biases (Rumelhart et al., 1986). These adjustments are performed based on the training dataset; meaning, the classification process is stopped when the difference between the neural network classification and the training dataset is minimized. From an operational point of view, this is achieved when the difference between two subsequent iterations is lower than a certain threshold, or the prearranged maximum number of iterations is reached. The algorithm requires two inputs: i) grid (raster) data, which are represented by the red, green, and blue (RGB) bands of the orthophoto obtained from the drone survey; and ii) the vector data defining the training areas, which are the detection targets. The detection targets (or labelled samples) were defined by manually tracing some of the weed spots as a polygon shapefile, in particular 11 polygons were traced scattered across the field comprising both single weeds and group of weeds in cases where they emerged closely, and a single weed couldn't be traced, the total area of these polygons was $2.21 \mathrm{~m}^{2}$. The parameters to be set are: i) the number of hidden layers of the neural network; ii) the number of neurons of the hidden layers; iii) the process stopping criteria (i.e., the maximum number of iterations and the minimum difference between the iteration thresholds); and iv) the activation function and learning rate parameters. Altogether, these parameters determine the structure and functioning of the OpenCV ANN (OpenCV, 2014).

The VARI index was developed by a group of scientists at the University of Nebraska, and its primary purpose is to calculate the vegetation indices whilst reducing the influence of atmospheric interference. It is based on a combination of the visible spectral bands (Formula 1) (Gitelson et al., 2002).

VARI $=($ Green-Red $) /($ Green + Red-Blue $)$

The VARI index is used for different purposes, mainly for measuring leaf area index (LAI) (Gitelson et al., 2003), as well as for monitoring crop health and even estimating fire hazard potential (Schneider et al., 2008; McKinnon and Hoff, 2017). However, in our research, the authors have not found references for the use of this index in weed detection. Similar to the OpenCV ANN, VARI was also computed on grid (raster) data, that is, RGB bands of the

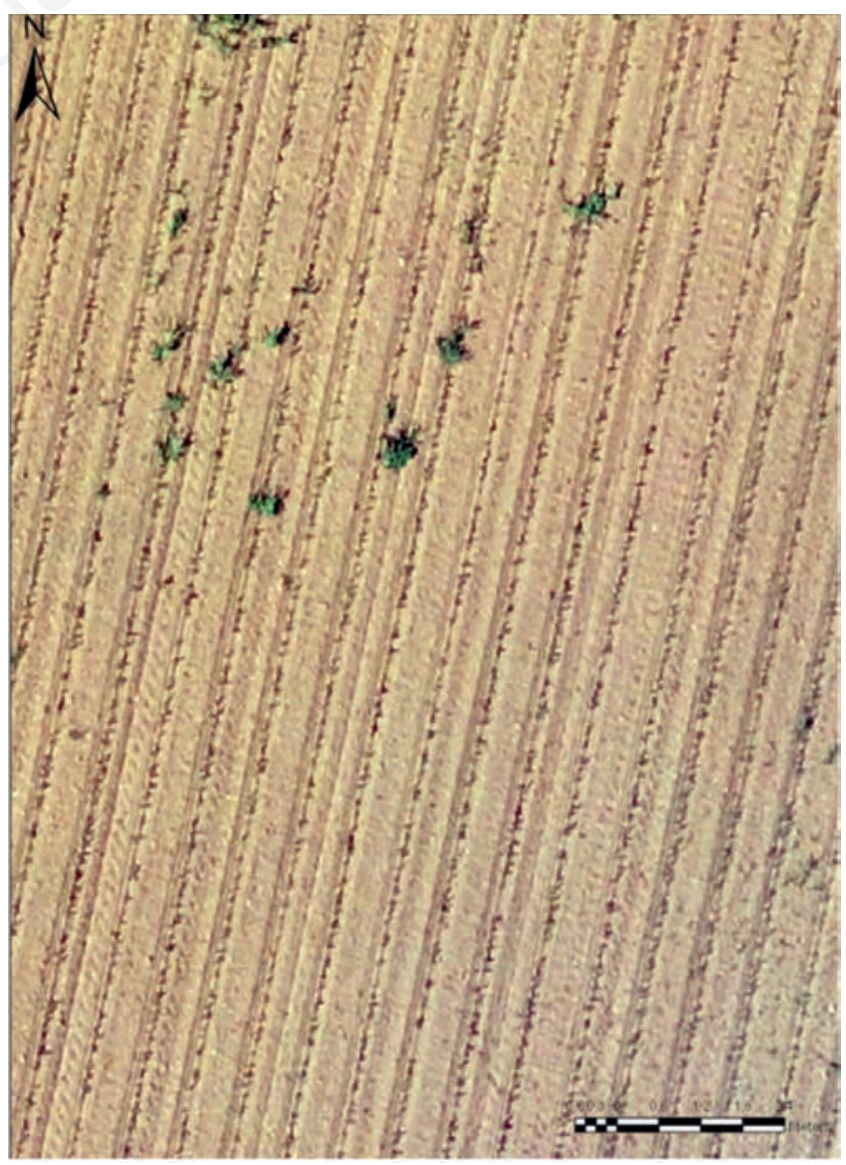

Figure 1. Sample of the orthophoto obtained (19 June 2019). 
orthophoto obtained from the drone survey. The VARI index is designed to be minimally sensitive to atmospheric effects (Gitelson et al., 2002; Schneider et al., 2008). As so, we computed it directly on the raw digital number values of the UAV images, i.e., without converting to reflectance. In addition, the flight conditions were constant. However, for further comparison, the illumination conditions might be considered to test the transferability of the method. In the derived raster, each pixel was attributed with a VARI value ranging from 0.16 to 1.67 . The raster was then classified into five classes using the optimization algorithm defined by Jenks. This algorithm minimizes the standard deviation within the single classes (i.e., the differences within each class) and maximizes the differences among classes, thus identifying so-called 'natural breaks'. The Jenk's algorithm is suggested to provide neutral class delineation in early spatial data mining (Murray and Shyy, 2000; Irigaray et al., 2007). Subsequently, it was necessary to conduct a reclassification to achieve only two categories: non-weed and weeds. To this end, we identified the threshold value for pixels identified as weeds by visually comparing the original orthophoto to the one with VARI values. Non-weed categories were the first three classes, corresponding to the interval of values $0.16 \leq$ non-weed $<0.08$, while the weed categories were the last two classes, corresponding to the interval $0.081 \leq$ weed $\leq 1.67$. The, Reclassify (Spatial Analyst) tool integrated into ArcGIS Pro was used to reclassify the pixels into two categories, non-weed, and weed.

\section{Accuracy assessment}

Image classification is one of the most frequently performed analyses on remote sensing data; because of this, classification accuracy has been widely addressed in the literature (Foody, 2008). Nonetheless, there is still an open debate about the multiple accuracy methods developed so far in the scientific community. A widely established method for accuracy assessment is the confusion matrix (Foody, 2002), which essentially allows the comparison of classified values with reference values (called 'field truth' or 'ground truth') using a contingency table (Cohen, 1960). In this study, the confusion matrix was computed within the SAGA GIS open-source software (version 7.6.2). For each class, two in this case (i.e., weed and notweed), the number of pixels is compared with those from the reference data (Story and Congalton, 1986). Reference data were produced by an expert classification through photointerpretation on the orthomosaic and was used to assess both methods. The accuracy assessment based on the confusion matrix included the computation of the overall accuracy, the commission error (false positive rate) and the omission error (false negative rate), as well as Cohen's Kappa that estimates the accuracy net of values due to chance (Congalton, 1991).

\section{Estimation of weed emergence percentage}

From the data gathered during the ground surveys seven days after sowing, when maize was in the initial growing stage (9-10 $\mathrm{BBCH}$ scale), that included the scouting for the weed species present, it was determined that plant infestation in the field was composed almost exclusively of Sorghum halepense. In order to determine the best time for a UAV survey, an AlertInf emergence predictive model was used. The soil temperature and daily precipitation levels comprised the AlertInf input data. Both the soil temperature, at $5 \mathrm{~cm}$ depth, and precipitation data were obtained from the meteorological stations of the Regional Agency for Environmental Protection (ARPA), located near the experimental field. Based on the data concerning the biology of Sorghum halepense and the meteorological data, AlertInf produced a cumulative emergence curve, showing the percentage of seedling emergence reached by the species relative to each day (Figure 2).

\section{Prescription maps}

Creating prescription maps was a three-stage process performed with ArcGIS Pro ModelBuilder, integrated into the ArcGIS Pro software (Figure 3). The first stage consisted of creating a precision spraying grid by dividing the field into regular cells. The cell size was chosen after considering the fundamental factors that determine the base area coverage for a sprayer: i) the spraying angle; ii) the altitude of the boom; and iii) the possibility of controlling a single nozzle or a boom section (Bajwa, 2014; Gonzalezde-Soto et al., 2016; Kluza et al., 2019; Partel et al., 2019). Next, three different cell sizes were defined based on the technical specifications of the most common models of sprayers for precision spraying available in the region (Toselli Srl; Kuhn Italia S.R.L.; Lemken $\mathrm{GmbH} \& \mathrm{Co}$. KG). These cell sizes were: $3.00 \mathrm{~m}^{2}, 2.00$ $\mathrm{m}^{2}$, and $0.25 \mathrm{~m}^{2}$ (Figure 4). The second stage comprised selecting the pixels classified as weeds in the outputs of the two weed classification methods (i.e., OpenCV ANN and VARI). Finally, in the third stage, each precision spraying grids intersected with the weed classification output to quantify weed infestation per cell. From here, each cell was classified: i) to be sprayed; or ii) not to be sprayed according to the weed infestation ratio. This classification was based on the three decision-making thresholds for spraying: more than $1 \%$, more than $5 \%$, and more than $10 \%$ of the pixels within a cell identified as weeds.

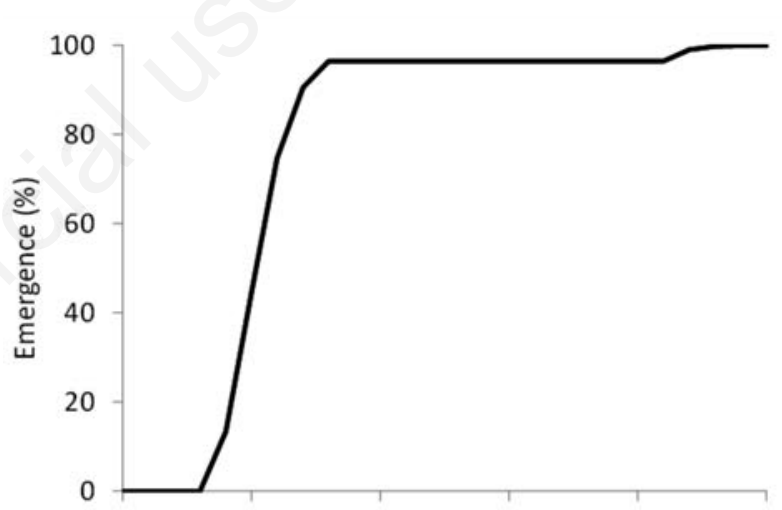

01/06/19 06/06/19 11/06/19 16/06/19 21/06/19 26/06/19

Figure 2. Cumulated emergence (\%) of Sorghum halepense in the field in 2019, simulated by the Alertinf model.

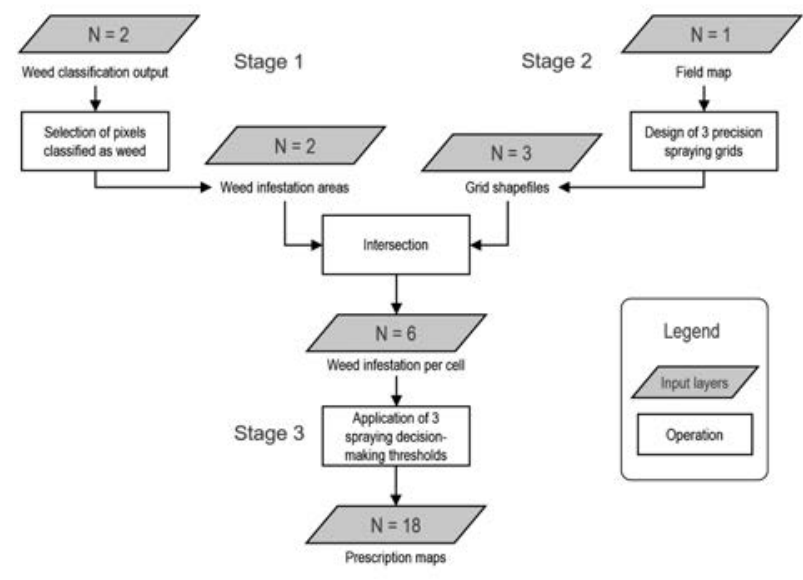

Figure 3. Prescription map creation workflow, $N$ is the number of inputs/outputs used/produced during the creation of prescription maps. 


\section{Herbicide use assessment}

The prescription maps issued from the previous step were used to assess the potential herbicide use reduction for the different classification methods and decision-making scenarios. For this purpose, two herbicides were considered, both registered in Italy for use in maize fields and the chemical control of Sorghum halepense (Banca dati dei prodotti fitosanitari, 2020). The first one was Equip (Foramsulfuron $2.33 \%=22.5 \mathrm{~g} / \mathrm{L}$, Isoxadifen-ethyl $2.33 \%=22.5$ $\mathrm{g} / \mathrm{L}$ ), with a recommended dose of $2.3 \mathrm{~L} / \mathrm{ha}$, corresponding to $53.75 €$ on the market, and the second one was Titus Mais Extra (Nicosulfuron p.a. pure $30 \mathrm{~g}$, Rimsulfuron p.a. pure $15 \mathrm{~g}$, Coformulants q.b. $100 \mathrm{~g}$ ), with a recommended dose of $80 \mathrm{~g} / \mathrm{ha}$, corresponding to $37.50 €$. The prices are indicative of the 2020 market price. The quantity for each herbicide (litres and grams) was calculated based on the area to be sprayed according to prescription maps and knowledge of how much product is needed for the whole field area, using simple proportions. Then, following the same procedure, treatment costs were calculated. In this way, both the reduction in the quantity of herbicides used and the related variable costs were obtained.

\section{Results and discussion}

Using the AlertInf model, the cumulative emergence percentage for Sorghum halepense in the experimental field was obtained. It was decided to carry out the survey with the UAV on the date that AlertInf predicted $96 \%$ of species emergence, allowing for a good mapping and efficient weed control operations. The date was also suitable considering meteorological parameters for the drone flight, phenological stage of the crop, and planned agronomical operations.

The OpenCV ANN method outperformed the VARI method in weed classification. In particular, the ANN showed a commission error (false positive) for weed classification almost five times lower than the VARI. However, the OpenCV ANN algorithm underestimated the weed occurrence compared to VARI, with an omission error (false negative) of $19.4 \%$ versus $6.0 \%$, respectively. The difference in commission/omission error between the two methods could also be one of the reasons to impact choosing one method over the other. From the environmentalist point of view, it is probably better to use the OpenCV ANN that would indicate lesser use of herbicides even if it means letting some of the weed plants survive. From the farmers' point of view, however, it is probably better to use the VARI method, that although it proposes the higher use of herbicides, it would also eliminate more weed, which could negatively impact the final yield if they are left untreated. Altogether, the overall accuracy of both classification methods is very high and quite similar, with $98.6 \%$ for OpenCV ANN and $98.1 \%$ for VARI classification. However, Cohen's Kappa indicated that the OpenCV ANN stands a greater chance of being accurate than the VARI thresholding (Table 1).

The combination of three precision spraying grids and three spraying thresholds produced nine prescription maps for each of the two orthomosaic classification methods: OpenCV ANN (Figure 5) and VARI (Figure 6).

Decision-making thresholds were chosen arbitrarily, considering the format of the data used, the weed species present, and the agronomic information available. There are different kinds of

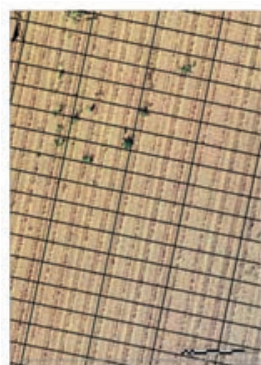

A

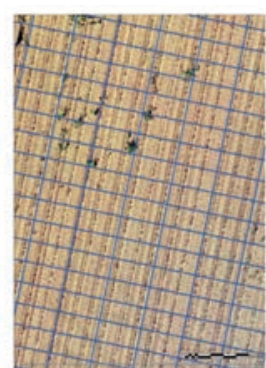

B
C

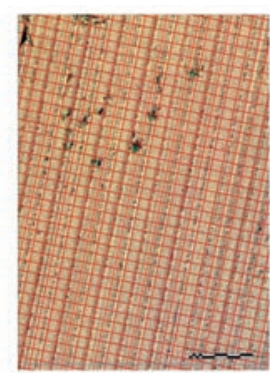

Figure 4. Sample of precision spraying grid with three cell sizes: $3.00 \mathrm{~m}^{2}(\mathrm{~A}), 2.00 \mathrm{~m}^{2}(\mathrm{~B})$, and $0.25 \mathrm{~m}^{2}(\mathrm{C})$.

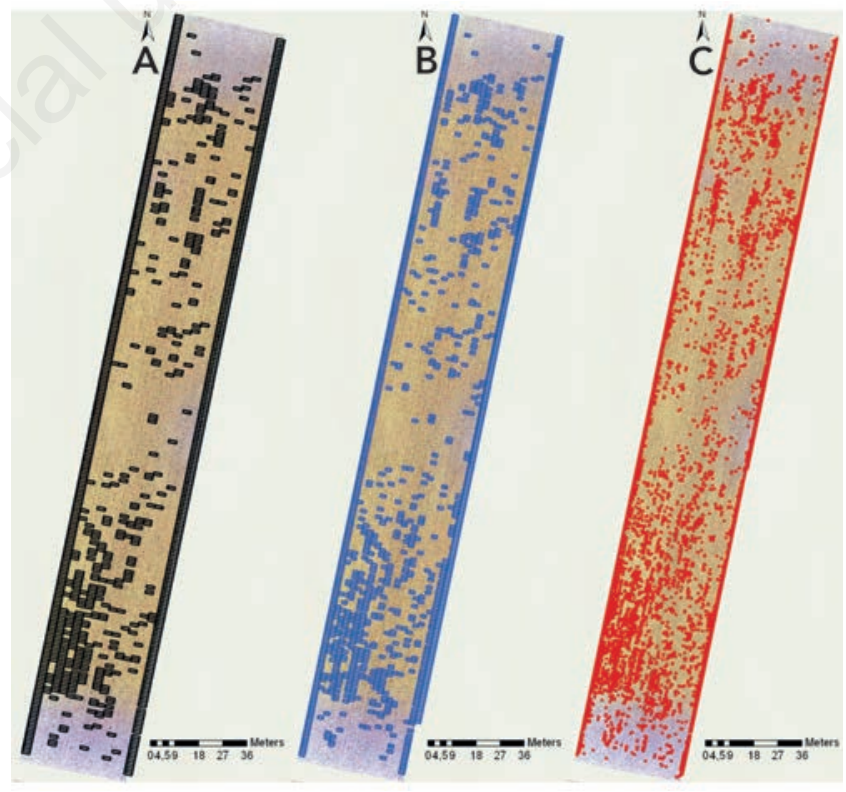

Figure 5. Comparison of the prescription maps for the OpenCV artificial neural network classification method. Examples for the $5 \%$ threshold for three cell sizes to be sprayed, namely: $3.00 \mathrm{~m}^{2}$ (A), $2.00 \mathrm{~m}^{2}(B)$, and $0.25 \mathrm{~m}^{2}(\mathrm{C})$.

Table 1. Accuracy assessment of the OpenCV ANN and VARI weed classification methods.

\begin{tabular}{|c|c|c|c|c|c|}
\hline Classification method & Classes & $\begin{array}{l}\text { Commission error } \\
\text { (false positive, } \% \text { ) }\end{array}$ & Omission error & $\begin{array}{l}\text { Overall accuracy (\%) } \\
\text { (false negative, } \% \text { ) }\end{array}$ & Cohen's Kappa (\%) \\
\hline OpenCV ANN & $\begin{array}{c}\text { Weed } \\
\text { No-weed }\end{array}$ & $\begin{array}{c}11.8 \\
1.0\end{array}$ & $\begin{array}{c}19.4 \\
0.5\end{array}$ & 98.6 & 83.7 \\
\hline VARI & $\begin{array}{c}\text { Weed } \\
\text { No-weed }\end{array}$ & $\begin{array}{c}40.2 \\
0.2\end{array}$ & $\begin{array}{l}6.0 \\
1.8\end{array}$ & 98.1 & 72.0 \\
\hline
\end{tabular}

ANN, artificial neural network; VARI, visible atmospherically resistant index 
thresholds and it is important to choose the most suitable one for the data being used (Coble and Mortensen, 1992). The most commonly used threshold is based on weed density, where the decision to spray is based on the number of weeds per area, which can be as low as 0.05 weeds $/ \mathrm{m}^{2}$ for some weed species (Auld and Tisdell, 1987; Zanin et al., 1994; Sartorato et al., 1996). For Sorghum halepense, this threshold is one plant per square meter (Roberts and Hayes, 1989; Ghoshen et al., 1996). Due to the inability to effectively count plants, considering that the datum is expressed in pixels, the thresholds have been translated into percentages of pixels marked as weeds in a specific area. This was performed in a manner like that used in the study done by López-Granados and colleagues (López-Granados et al., 2016), where the chosen thresholds ranged from $0 \%$ to $15 \%$ of the pixels marked as weed $/ \mathrm{m}^{2}$. The three thresholds chosen are also very low because the cell sizes are smaller or greater than $1 \mathrm{~m}^{2}$, which is not an isolated case (Mortensen et al., 1995; Keller et al., 2014).

Nevertheless, it requires thoroughly considering the thresholds to use, making them comparable between different prescription maps created. These maps allowed for a comparison between the different cell sizes and decision-making thresholds and between the two classification methods. The possible reduction of the area to be sprayed and the differences in the area classified for spraying between the two classification methods were calculated for a field 1 ha large (Table 2).

The reduction in the area to be sprayed using the prescription maps is significant compared to traditional spraying, which comprises spraying the entire field. Depending on the cell size and the threshold percentage for decision making, the area reduction for spraying can go from $65.29 \%$ to $93.35 \%$ with the VARI classification and from $42.43 \%$ to $87.82 \%$ with the OpenCV ANN classification. However, these data should be considered with caution, taking into account the classification precision, the level of infestation where, in the case of complete coverage by the weeds, blanket spraying might be the only option; and the potential damage that can be caused by the plants that could be skipped during the field treatment using this method. This may result in possible damage to crops caused by inadequate herbicide targeting (Hall et al., 2000; Kudsk and Streibig, 2003; Wolf, 2009; Lottes et al., 2017).

It is also important to emphasize that the authors have set the decision-making thresholds arbitrarily based on their experiences to observe the changes in the area to be sprayed. Therefore, while they could, they should not necessarily be considered as thresholds to use. The progress in spatial detection of weeds is also followed by the progress in technologies for precise herbicide application, which is one of the key points allowing the creation of prescription maps and the reduction in the quantity of herbicides used (Gopalapillai et al., 1999; Baillie et al., 2013; Gerhards, 2013; Gonzalez-de-Soto et al., 2016; Partel et al., 2019). By modelling the possible reduction in cost and amount of the two herbicides used, it is evident that a reduction in their use is dependent on the reduction of the area to be treated. Therefore, it is also highly dependent on the classification precision and on the precision of systems for herbicide application, translated to cells of prescription maps. As so, we computed the reduction in the quantity and costs comparing the two classification methods, whilst considering different decision-making thresholds, both for Equip (Table 3) and Titus Mais Extra (Table 4). In the tables, the cost of effective quantity needed for treatment of the area proposed by the methods is shown in the columns 'cost', while in the columns 'savings,' it is

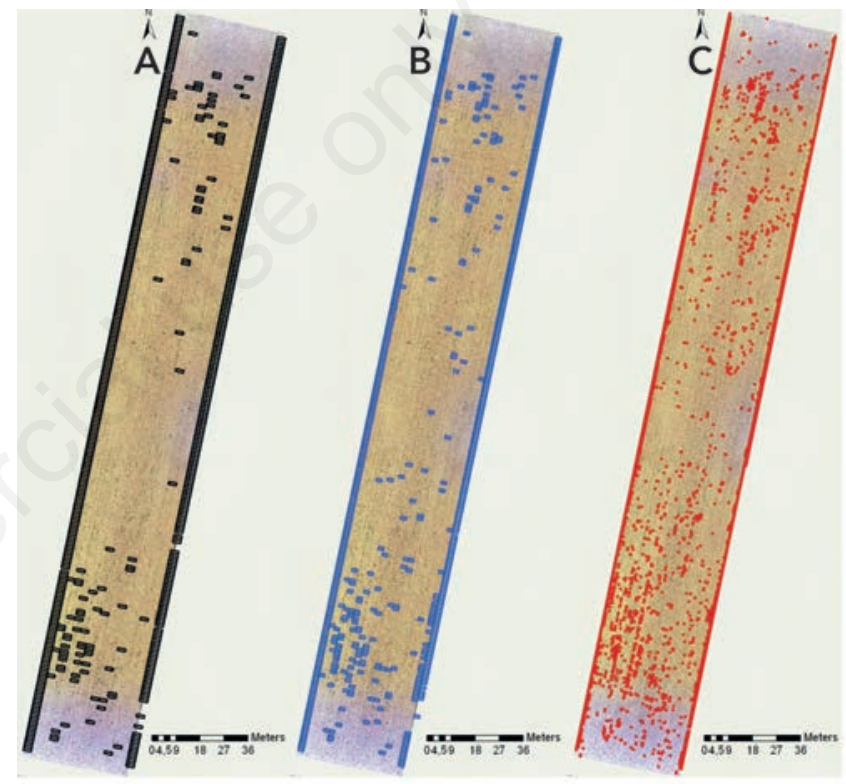

Figure 6. Comparison of the prescription maps for the visible atmospherically resistant index classification method. Examples for the $5 \%$ threshold for three cell sizes to be sprayed, namely: $3.00 \mathrm{~m}^{2}(\mathrm{~A}), 2.00 \mathrm{~m}^{2}(\mathrm{~B})$, and $0.25 \mathrm{~m}^{2}(\mathrm{C})$.

Table 2. Possible spraying area reduction in a field of 1 ha.

\begin{tabular}{|c|c|c|c|c|c|c|}
\hline & & & VARI & & & \\
\hline & $1 \%$ in & tation & $5 \%$ infes & tion & $10 \%$ inf & ation \\
\hline Cell size & Area to be sprayed (ha) & Reduction \% & Area to be sprayed (ha) & Reduction \% & Area to be sprayed (ha) & Reduction \% \\
\hline $0.25 \mathrm{~m}^{2}$ & 0.35 & 65.29 & 0.19 & 80.59 & 0.15 & 85.36 \\
\hline $2.00 \mathrm{~m}^{2}$ & 0.15 & 85.33 & 0.15 & 84.82 & 0.11 & 88.88 \\
\hline $3.00 \mathrm{~m}^{2}$ & 0.12 & 88.05 & 0.09 & 91.42 & 0.07 & 93.35 \\
\hline & $1 \%$ infest & & $\begin{array}{r}\text { OpenCV ANN } \\
5 \% \text { infes }\end{array}$ & tion & $10 \%$ int & ation \\
\hline Cell size & Area to be sprayed (ha) & Reduction \% & Area to be sprayed (ha) & Reduction \% & Area to be sprayed (ha) & Reduction \% \\
\hline $0.25 \mathrm{~m}^{2}$ & 0.58 & 42.43 & 0.30 & 69.97 & 0.21 & 78.94 \\
\hline $2.00 \mathrm{~m}^{2}$ & 0.50 & 49.7 & 0.26 & 73.72 & 0.17 & 83.00 \\
\hline $3.00 \mathrm{~m}^{2}$ & 0.22 & 77.57 & 0.16 & 84.03 & 0.12 & 87.82 \\
\hline
\end{tabular}

VARI, visible atmospherically resistant index; ANN, artificial neural network. 
shown how much money can be saved by treating only the area proposed by the methods compared to the cost of herbicides quantity necessary for the treatment of the whole field.

For Equip (Table 3), it is possible to see great differences in the reduction of quantity used and in savings between both the classification methods and decision-making thresholds. For the OpenCV ANN classification, the quantity used can go from $1.32 \mathrm{~L} /$ ha to $0.28 \mathrm{~L} / \mathrm{ha}$, a significant reduction considering that the quantity used would be $2.3 \mathrm{~L} /$ ha with blanket spraying. As a consequence, the savings can go from $22.81 € /$ ha to $47.20 € /$ ha, again an important cost reduction considering that for the traditional spraying, the cost would be $53.75 € /$ ha. As for the VARI classification, the quantity used can go from $0.80 \mathrm{~L} /$ ha to $0.15 \mathrm{~L} / \mathrm{ha}$, which is notable considering the quantity needed for traditional spaying. Moreover, the savings are significant for VARI, going from $35.09 € /$ ha to 50.18 $€ /$ ha. Also, for Titus Mais Extra (Table 4) is possible to observe important differences in reducing the quantity of herbicides used and the associated savings between both the classification methods and decision-making thresholds. For the OpenCV ANN classification, the quantity used can go from $46.06 \mathrm{~g} / \mathrm{ha}$ to $8.19 \mathrm{~g} / \mathrm{ha}$, a notable reduction considering that the quantity used would be 80 $\mathrm{g} / \mathrm{ha}$ for traditional spraying.
Meanwhile, the savings can go from $15.91 € /$ ha to $32.93 € /$ ha, which is also very important considering that the cost would be $37.5 € /$ ha for traditional spraying. For VARI classification, the quantity can go from $27.77 \mathrm{~g} / \mathrm{ha}$ to $5.32 \mathrm{~g} / \mathrm{ha}$, both much lower than the $80 \mathrm{~g} /$ ha required for blanket spraying. Furthermore, the savings are also high, ranging from $24.48 € /$ ha to $35.01 € /$ ha. All prices are indicative of the 2020 market value.

It is important to note that despite differences in the quantity of spraying required between the two methodologies used and different decision-making thresholds, they offer a substantial reduction in herbicide use compared to traditional spraying. Consequential cost reduction can also be significant, especially if the area to be treated is extensive. These results are similar to the results from different studies done worldwide. For example, in their work, Slaughter et al. (1999) found that by implementing precision spraying, the area to be sprayed can be reduced from $100 \%$ to approximately $57 \%$, making the chemical weed control 3.7 times more efficient. Additionally, Hamouz et al. (2013) found that the reduction in herbicide application can increase from $15.6 \%$ to $100 \%$, depending on the different methodologies and thresholds used. The authors also agree that a higher decision-making threshold equates to more herbicide savings. Other works, such as that

Table 3. Possible savings associated with various degrees of quantity reductions of herbicide (Equip).

\begin{tabular}{|c|c|c|c|c|c|c|c|c|c|}
\hline Cell size & $\begin{array}{c}\text { Quantity } \\
\text { (L/ha) }\end{array}$ & $\begin{array}{c}1 \% \\
\text { Cost } \\
(€ / h a)\end{array}$ & $\begin{array}{l}\text { Savings } \\
(€ / h a)\end{array}$ & $\begin{array}{l}\text { OpenCV ANI } \\
\text { Quantity } \\
\text { (L/ha) }\end{array}$ & $\begin{array}{c}5 \% \\
\text { Cost } \\
(€ / h a)\end{array}$ & $\begin{array}{l}\text { Savings } \\
\text { (€/ha) }\end{array}$ & $\begin{array}{c}\text { Quantity } \\
\text { (L/ha) }\end{array}$ & $\begin{array}{c}10 \% \\
\text { Cost } \\
(€ / h a)\end{array}$ & $\begin{array}{l}\text { Savings } \\
\text { (€/ha) }\end{array}$ \\
\hline $3.00 \mathrm{~m}^{2}$ & 1.32 & 30.94 & 22.81 & 0.69 & 16.14 & 37.61 & 0.48 & 11.32 & 42.43 \\
\hline $2.00 \mathrm{~m}^{2}$ & 1.16 & 27.04 & 26.71 & 0.60 & 14.13 & 39.63 & 0.39 & 9.14 & 44.61 \\
\hline $0.25 \mathrm{~m}^{2}$ & 0.52 & 12.06 & 41.70 & 0.37 & 8.58 & 45.17 & 0.28 & 6.55 & 47.20 \\
\hline Cell size & $\begin{array}{c}\text { Quantity } \\
\text { (L/ha) }\end{array}$ & $\begin{array}{c}1 \% \\
\text { Cost } \\
(€ / h a)\end{array}$ & $\begin{array}{l}\text { Savings } \\
(€ / h a)\end{array}$ & $\begin{array}{l}\text { VARI } \\
\text { Quantity } \\
\text { (L/ha) }\end{array}$ & $\begin{array}{c}5 \% \\
\text { Cost } \\
\text { (€/ha) }\end{array}$ & $\begin{array}{l}\text { Savings } \\
\text { (€/ha) }\end{array}$ & $\begin{array}{c}\text { Quantity } \\
\text { (L/ha) }\end{array}$ & $\begin{array}{c}10 \% \\
\text { Cost } \\
\text { (€/ha) }\end{array}$ & $\begin{array}{l}\text { Savings } \\
\text { (€/ha) }\end{array}$ \\
\hline $3.00 \mathrm{~m}^{2}$ & 0.80 & 18.66 & 35.09 & 0.45 & 10.43 & 43.32 & 0.34 & 7.87 & 45.88 \\
\hline $2.00 \mathrm{~m}^{2}$ & 0.34 & 7.89 & 45.87 & 0.35 & 8.16 & 45.6 & 0.26 & 5.98 & 47.77 \\
\hline $0.25 \mathrm{~m}^{2}$ & 0.28 & 6.42 & 47.33 & 0.20 & 4.61 & 49.14 & 0.15 & 3.57 & 50.18 \\
\hline
\end{tabular}

ANN, artificial neural network; VARI, visible atmospherically resistant index.

Table 4. Possible savings associated with various degrees of quantity reductions of herbicide (Titus Mais Extra).

\begin{tabular}{|c|c|c|c|c|c|c|c|c|c|}
\hline & & & & OpenCV AN & & & & & \\
\hline Cell size & $\begin{array}{l}\text { Quantity } \\
\text { (g/ha) }\end{array}$ & $\begin{array}{c}1 \% \\
\text { Cost } \\
(€ / h a)\end{array}$ & $\begin{array}{l}\text { Savings } \\
\text { (€/ha) }\end{array}$ & $\begin{array}{c}\text { Quantity } \\
\text { (g/ha) }\end{array}$ & $\begin{array}{c}5 \% \\
\text { Cost } \\
(€ / h a)\end{array}$ & $\begin{array}{l}\text { Savings } \\
\text { (€/ha) }\end{array}$ & $\begin{array}{l}\text { Quantity } \\
\text { (g/ha) }\end{array}$ & $\begin{array}{c}10 \% \\
\text { Cost } \\
(€ / h a)\end{array}$ & $\begin{array}{c}\text { Savings } \\
\text { (€/ha) }\end{array}$ \\
\hline $3.00 \mathrm{~m}^{2}$ & 46.06 & 21.59 & 15.91 & 24.02 & 11.26 & 26.24 & 16.85 & 7.90 & 29.60 \\
\hline $2.00 \mathrm{~m}^{2}$ & 40.24 & 18.86 & 18.64 & 21.02 & 9.86 & 27.65 & 13.60 & 6.38 & 31.13 \\
\hline $0.25 \mathrm{~m}^{2}$ & 17.94 & 8.41 & 29.09 & 12.78 & 5.99 & 31.51 & 9.74 & 4.57 & 32.93 \\
\hline Cell size & $\begin{array}{l}\text { Quantity } \\
\text { (g/ha) }\end{array}$ & $\begin{array}{c}1 \% \\
\text { Cost } \\
(€ / h a)\end{array}$ & $\begin{array}{l}\text { Savings } \\
\text { (€/ha) }\end{array}$ & $\begin{array}{c}\text { VARI } \\
\text { Quantity } \\
\text { (g/ha) }\end{array}$ & $\begin{array}{c}5 \% \\
\text { Cost } \\
(€ / h a)\end{array}$ & $\begin{array}{l}\text { Savings } \\
\text { (€/ha) }\end{array}$ & $\begin{array}{l}\text { Quantity } \\
\text { (g/ha) }\end{array}$ & $\begin{array}{c}10 \% \\
\text { Cost } \\
(€ / h a)\end{array}$ & $\begin{array}{l}\text { Savings } \\
\text { (€/ha) }\end{array}$ \\
\hline $3.00 \mathrm{~m}^{2}$ & 27.77 & 13.02 & 24.48 & 15.53 & 7.28 & 30.22 & 11.71 & 5.49 & 32.01 \\
\hline $2.00 \mathrm{~m}^{2}$ & 11.74 & 5.50 & 32.00 & 12.14 & 5.69 & 31.81 & 8.90 & 4.17 & 33.33 \\
\hline $0.25 \mathrm{~m}^{2}$ & 9.56 & 4.48 & 33.02 & 6.87 & 3.22 & 34.28 & 5.32 & 2.49 & 35.01 \\
\hline
\end{tabular}

ANN, artificial neural network; VARI, visible atmospherically resistant index. 
done by Takács-György (2008), indicate that by implementing precision weed controlling tactics, the reduction of herbicide usage can be substantial, and so can the savings. This author also implies that the initial investments in precision agriculture are paid off in a few years due to the savings they allow.

\section{Conclusions}

Because of the herbicide traits that make them harmful to the environment and health, their application must be improved and reduced. In this study, an innovative approach that combines sitespecific and time-specific weed management methods are presented. As is, the method could improve the performance of UAV image classification for weed detection. Moreover, by implementing the proposed method, it is possible to reduce the amount of herbicide used, which also reduces agricultural production costs. Overall, the two classification approaches used have both positive and negative traits.

On the one hand, while the OpenCV ANN produced a better classification than VARI, it required more training and was more time-consuming. On the other hand, the VARI algorithm showed some limitations in weed classification, yet it was much more straightforward to use and thus required much less time. As stated before, the efficacy of the treatment depends on the threshold for decision making and the cell size chosen. It is, therefore, up to the end-user to decide which combination could suit his/her needs better. However, as a general rule for better efficacy, one should consider using lower thresholds with bigger cells, while from an economic perspective using higher thresholds with smaller cells could also give good results. We have shown that adding a temporal component to precision weed detection could be very useful for herbicide reduction, as it offers information about the percentage of weed emergence in time. Indeed, with the temporal AlertInf weed detection model, it was possible to better organize the UAV survey to map the maximum number of weeds possible according to the percentage of weed emergence and the development stage of the crops.

Moreover, if the correct timing for UAV surveys is chosen, the resulting prescription maps will contain a majority of weed plants that could infest the field, thus potentially improving the spatial detection of the most relevant weed(s). As a consequence, given the proper use of herbicides, it might be possible to reduce the herbicide amount used and eliminate the need for subsequent chemical herbicide treatments. This could be a leap forward, considering that the percentage of emerged weeds is not considered with the traditional weed controlling methods. Consequently, in some cases, after the first spraying, the weeds that have not yet emerged create a second flush of infestation, compelling the farmers to undergo a second round of herbicide treatment in order to prevent reduced crop yield. However, with fewer and more efficient treatments, the problem of herbicide resistance could be attenuated.

Nevertheless, consider that the present experiment is modular and theoretical; therefore, it is necessary to transfer it to real situations by conducting field trials. With the field trials, it will be possible to understand how applicable these methods are and determine if the efficacy achieved corresponds to the one simulated. It would also be possible to understand better the problems that may occur in real-life applications and resolve them. Finally, comparing the final yield from a field in which precision weed control methods were applied with one in which they were not applied would provide valuable insight for a cost-benefit analysis. Other than what has been mentioned before, further studies are required in order to be able to address different production methods, with more cultivated species and more weed species, in order to meet market demands. It could also be very useful to collaborate with the sprayer production industry to develop increasingly more precise spraying systems. Additionally, calibration of weed emergence predictive models for use in different parts of the world must also be performed so that they may be able to apply the techniques presented in this work beyond the Veneto region.

\section{References}

Arriaga FJ, Guzman J, Lowery B, 2017. Conventional agricultural production systems and soil functions. In: Soil Health and Intensification of Agroecosytems. Elsevier, Amsterdam, The Netherlands, pp 109-25.

Astatkie T, Rifai MN, Havard P, Adsett J, Lacko-Bartosova M, Otepka P, 2007. Effectiveness of hot water, infrared and open flame thermal units for controlling weeds. Biol. Agric. Hortic. 25:1-12.

Auld BA, Tisdell CA, 1987. Economic thresholds and response to uncertainty in weed control. Agric. Syst. 25:219-27.

Ayerdi Gotor A, Marraccini E, Leclercq C, Scheurer O, 2020. Precision farming uses typology in arable crop-oriented farms in northern France. Precis. Agric. 21:131-46.

Baillie C, Fillols E, McCarthy C, Rees S, Staier T, 2013. Evaluating commercially available precision weed spraying technology for detecting weeds in sugarcane farming systems. Sugar Res. Aust. Ltd., 1-88.

Bajwa AA, 2014. Sustainable weed management in conservation agriculture. Crop Prot. 65:105-13. Available from: https://www.sciencedirect.com/science/article/pii/S026121941 4002348?via\%3Dihub

Ballesteros R, Ortega JF, Hernández D, Moreno MA, 2014. Applications of georeferenced high-resolution images obtained with unmanned aerial vehicles. Part II: application to maize and onion crops of a semi-arid region in Spain. Precis. Agric. 15:593-614.

Banca dati dei prodotti fitosanitari, 2020. Ministero della Salute Available from: http:/www.fitosanitari.salute.gov.it/fitosanitariws Web_new/FitosanitariServlet?ACTION=cerca Sostanza\&FROM=0\&TO=49\&PROVENIENZA=LISTA\&SO $\mathrm{ST}=1230$

Bareth G, Aasen H, Bendig J, Gnyp ML, Bolten A, Jung A, Michels R, Soukkamäki J, 2015. Low-weight and UAV-based hyperspectral full-frame cameras for monitoring crops: spectral comparison with portable spectroradiometer measurements. Photogramm. - Fernerkundung - Geoinf. 2015:69-79.

Beasley VR, 2020. Direct and Indirect effects of environmental contaminants on amphibians, 2nd edn. Elsevier Inc., Amsterdam, The Netherlands.

Borra-Serrano I, Peña JM, Torres-Sánchez J, Mesas-Carrascosa FJ, López-Granados F, 2015. Spatial quality evaluation of resampled unmanned aerial vehicle-imagery for weed mapping. Sensors 15:19688-708.

Bradford KJ, 2002. Applications of hydrothermal time to quantifying and modeling seed germination and dormancy. Weed Sci. 50:248-60.

Candiago S, Remondino F, De Giglio M, Dubbini M, Gattelli M, 2015. Evaluating multispectral images and vegetation indices for precision farming applications from UAV images. Remote Sens. 7:4026-47. 
Cerrudo D, Page ER, Tollenaar M, Stewart G, Swanton CJ, 2012. Mechanisms of yield loss in maize caused by weed competition. Weed Sci. 60:225-32.

Coble HD, Mortensen DA, 1992. The threshold concept and its application to weed science P. Weed Technol. 6:191-5.

Cohen J, 1960. A coefficient of agreement for nominal scales. Educ. Psychol. Meas. 20:37-46.

Colbach N, Chauvel B, Gauvrit C, Munier-Jolain NM, 2007. Construction and evaluation of ALOMYSYS modelling the effects of cropping systems on the blackgrass life-cycle: From seedling to seed production. Ecol. Modell. 201:283-300.

Congalton RG, 1991. A review of assessing the accuracy of classifications of remotely sensed data. Remote Sens. Environ. 37:35-46.

Dorado J, Sousa E, Calha IM, González-Andújar JL, FernándezQuintanilla C, 2009. Predicting weed emergence in maize crops under two contrasting climatic conditions. Weed Res. 49:251-60.

Elmolla ES, Chaudhuri M, Eltoukhy MM, 2010. The use of artificial neural network (ANN) for modeling of COD removal from antibiotic aqueous solution by the Fenton process. J. Hazard. Mater. 179:127-34.

European Food Safety Authority, 2018. The 2016 European Union report on pesticide residues in food. EFSA J. 16.

European Parliament, 2009. Regulation (EC) No 1107/2009. Off. J. Eur. Union 309:1-50. Available from: http://eurlex.europa.eu/LexUriServ/LexUriServ.do?uri=OJ:L:2009:309: 0001:0050:en:PDF

FAO, 2006. World Reference Base for Soil Resources. World Soil Resources Report 103. Rome, Italy.

FAO, 2014. Conservation agriculture. Conserv. Agric. Available from: http://www.fao.org/conservation-agriculture/en/

FAO/WHO, 2016a. The international code of conduct on pesticide management: guidelines on highly hazardous pesticides. Available from: www.fao.org/publications

FAO/WHO, 2016b. Manual on development and use of FAO and WHO specifications for pesticides.

Foody GM, 2002. Status of land cover classification accuracy assessment. Remote Sens. Environ. 80:185-201.

Foody G, 2008. Harshness in image classification accuracy assessment. Int. J. Remote Sens. 29:3137-58.

Forcella F, Benech Arnold RL, Sanchez R, Ghersa CM, 2000. Modeling seedling emergence. F. Crop. Res. 67:123-39.

Gaillard G, 2005. Life cycle assessment of agricultural production systems: current issues and future perspectives. Int. Semin. Technol. Dev. Good Agric. Pract. Asia Ocean. 98-110.

Gerhards R, 2013. Site-specific weed control. In: H. Heege (Ed.), Precision in crop farming: site specific concepts and sensing methods: applications and results. Springer Netherlands, Dordrecht, The Netherlands, pp. 273-94.

Ghoshen HZ, Holshouser DL, Chandler JM, 1996. Influence of density on johnsongrass (Sorghum halepense) interference in field corn (Zea mays). Weed Res. 44:879-83.

Giacomo R, David G, 2017. Unmanned aerial systems (UAS) in agriculture: regulations and good practices. E-Agriculture in action: drones for agriculture. Available from: https://www.fao.org/3/i8494en/i8494en.pdf

Gimsing AL, Agert J, Baran N, Boivin A, Ferrari F, Gibson R, Hammond L, Hegler F, Jones RL, König W, Kreuger J, van der Linden T, Liss D, Loiseau L, Massey A, Miles B, Monrozies L, Newcombe A, Poot A, Reeves GL, Reichenberger S, Rosenbom AE, Staudenmaier H, Sur R, Schwen A, Stemmer M, Tüting W, Ulrich U, 2019. Conducting groundwater moni- toring studies in Europe for pesticide active substances and their metabolites in the context of Regulation (EC) 1107/2009. J. Consumer Prot. Food Safety 14:1-93.

Gitelson AA, Stark R, Rundquist D, Gitelson AA, Kaufman YJ, Stark R, Rundquist D, 2002. Novel algorithms for remote estimation of vegetation fraction. Remote Sens. Environ. 80:79-87.

Gitelson AA, Vina A, Arkebauer TJ, Rundquist DC, Keydan G, Leavitt B, 2003. Remote estimation of leaf area index and green leaf biomass in maize canopies. Geophys. Res. Lett. 30:0-5.

Gonzalez-de-Soto M, Emmi L, Perez-Ruiz M, Aguera J, Gonzalezde-Santos P, 2016. Autonomous systems for precise spraying Evaluation of a robotised patch sprayer. Biosyst. Eng. 146:165-82.

Gopalapillai S, Tian L, Zheng J, 1999. Evaluation of a flow control system for site-specific herbicide applications. Trans. Am. Soc. Agric. Eng. 42:863-70.

Gupta PK, 2018. Toxicity of herbicides. In: G.C. Ramesh (Ed.), Veterinary toxicology: basic and clinical principles: third edition, Third Edit. Elsevier Inc., Amsterdam, The Netherlands, pp 553-67.

Hall JC, Van Eerd LL, Miller SD, Micheal DK, Prather TS, Shaner DL, Singh M, Vaughn KC, Stephen C, Prather TS, Shaner DL, Singh M, Vaughn KC, 2000. Future research directions for weed science. Weed Technol. 14:647-58.

Hamouz P, Hamouzová K, Holec J, Tyšer L, 2013. Impact of sitespecific weed management on herbicide savings and winter wheat yield. Plant Soil Environ. 59:101-7.

Hanzlik K, Gerowitt B, 2016. Methods to conduct and analyse weed surveys in arable farming: a review. Agron. Sustain. Dev. 36:1-18.

Hasenbein S, Peralta J, Lawler SP, Connon RE, 2017. Environmentally relevant concentrations of herbicides impact non-target species at multiple sublethal endpoints. Sci. Total Environ. 607-608:733-43.

Hassanein M, El-Sheimy N, 2018. An efficient weed detection procedure using low-cost UAV imagery system for precision agriculture applications. Int. Arch. Photogramm. Remote Sens. Spat. Inf. Sci. ISPRS Arch. 42:181-7.

Heap I, LeBaron H, 2001. Introduction and overview of resistance. In: S.B. Powels, D.L. Shaner (Eds.), Herbicide resistance and world grains. CRC Press LLC, Boca Raton, FL, USA, pp. 12-33.

Herwitz SR, Johnson LF, Dunagan SE, Higgins RG, Sullivan DV, Zheng J, Lobitz BM, Leung JG, Gallmeyer BA, Aoyagi M, Slye RE, Brass JA, 2004. Imaging from an unmanned aerial vehicle: agricultural surveillance and decision support. Comput. Electron. Agric. 44:49-61.

Holt JS, 2013. Herbicides. Encycl. Biodivers. Second Ed. 4:87-95.

Huang Y, Reddy KN, Fletcher RS, Pennington D, 2018. UAV lowaltitude remote sensing for precision weed management. Weed Technol. 32:2-6.

Hussain M, Farooq S, Merfield C, Jabran K, 2018. Mechanical weed control. In: K. Jabran, B.S. Chauhan (Eds.), Non-chemical weed control, 1st edn. Elsevier Inc., Amsterdam, The Netherlands, pp. 133-55.

Idowu J, Angadi S, 2013. Understanding and managing soil compaction in agricultural fields. Circ. 672:1-8.

Imoloame EO, Omolaiye JO, 2017. Weed infestation, growth and yield of maize (Zea mays L.) as influenced by periods of weed interference. Adv. Crop Sci. Technol. 05.

Irigaray C, Fernández T, El Hamdouni R, Chacón J, 2007. Evaluation and validation of landslide-susceptibility maps obtained by a GIS matrix method: examples from the Betic 
Cordillera (southern Spain). Nat. Hazards 41:61-79.

Keller M, Gutjahr C, Möhring J, Weis M, Sökefeld M, Gerhards R, 2014. Estimating economic thresholds for site-specific weed control using manual weed counts and sensor technology: An example based on three winter wheat trials. Pest Manag. Sci. 70:200-11.

Kluza PA, Kuna-Broniowska I, Parafiniuk S, 2019. Modeling and prediction of the uniformity of spray liquid coverage from flat fan spray nozzles. Sustain. 11.

Koot TM, 2014. Weed detection with unmanned aerial vehicles in agricultural systems. Wageningen University. Available from: http://edepot.wur.nl/333537

Kudsk P, Streibig JC, 2003. Herbicides - a two-edged sword. Weed Res. 43:90-102.

Lambert JPT, Hicks HL, Childs DZ, Freckleton RP, 2018. Evaluating the potential of Unmanned aerial systems for mapping weeds at field scales: a case study with Alopecurus myosuroides. Weed Res. 58:35-45.

Lingenfelter DD, Hartwig NL, 2013. Introduction to weeds and herbicides. Ag Commun. Mark. Pennsylvania State Univ., 138.

Lobley M, Potter C, 2004. Agricultural change and restructuring: Recent evidence from a survey of agricultural households in England. J. Rural Stud. 20:499-510.

López-Granados F, 2011. Weed detection for site-specific weed management: mapping and real-time approaches. Weed Res. 51:1-11.

López-Granados F, Torres-Sánchez J, Serrano-Pérez A, de Castro AI, Mesas-Carrascosa FJ, Peña JM, 2016. Early season weed mapping in sunflower using UAV technology: variability of herbicide treatment maps against weed thresholds. Precis. Agric. 17:183-99.

Lottes P, Khanna R, Pfeifer J, Siegwart R, Stachniss C, 2017. UAV-based crop and weed classification for smart farming. $p p$ 3024-31 in Proc. - IEEE Int. Conf. Robot. Autom.

Lyon DJ, Miller SD, Wicks GA, 1996. The future of herbicides in weed control systems of the Great Plains. J. Prod. Agric. 9:209-15.

Maes WH, Steppe K, 2019. Perspectives for remote sensing with unmanned aerial vehicles in precision agriculture. Trends Plant Sci. 24:152-64.

Martín CS, Andújar D, Fernández-Quintanilla C, Dorado J, 2015. Spatial distribution patterns of weed communities in corn fields of central spain. Weed Sci. 63:936-45.

Masin R, Cacciatori G, Zuin MC, Zanin G, 2010. AlertInf: Emergence predictive model for weed control in maize in Veneto. Ital. J. Agrometeorol. 5.

Masin R, Loddo D, Benvenuti S, Otto S, Zanin G, 2012. Modeling weed emergence in Italian maize fields. Weed Sci. 60:254-9.

Masin R, Loddo D, Gasparini V, Otto S, Zanin G, 2014. Evaluation of weed emergence model AlertInf for maize in soybean. Weed Sci. 62:360-9.

McKinnon T, Hoff P, 2017. Comparing RGB-based vegetation indices with NDVI for drone based agricultural sensing. Agribotix 1-8.

Melander B, Rasmussen IA, Bàrberi P, 2005. Integrating physical and cultural methods of weed control - examples from European research. Weed Sci. 53:369-81.

Mohler CL, 1996. Ecological bases for the cultural control of annual weeds. J. Prod. Agric. 9:468-74.

Morales MAM, Camargo B de CV, Hoshina MM, 2013. Toxicity of herbicides: impact on aquatic and soil biota and human health. In: A. Price, J. Kelton (Eds.), Herbicides: current research and case studies in use. IntechOpen Ltd., London, UK, pp 399-443.

Mortensen DA, Johnson GA, Wyse DY, Martin AR, 1995. Managing spatially variable weed populations. pp 395-415 in P.C. Robert, R.H. Rust, W.E. Larson (Eds.), Site $\square$ specific management for agricultural systems. American Society of Agronomy.

Murat YS, Ceylan H, 2006. Use of artificial neural networks for transport energy demand modeling. Energy Policy 34:3165-72.

Murray AT, Shyy TK, 2000. Integrating attribute and space characteristics in choropleth display and spatial data mining. Int. J. Geogr. Inf. Sci. 14:649-67.

Myers MW, Curran WS, VanGessel MJ, Calvin DD, Mortensen DA, Majek BA, Karsten HD, Roth GW, 2004. Predicting weed emergence for eight annual species in the northeastern United States. Weed Sci. 52:913-9.

OpenCV, 2014. Neural networks. Available from: https://docs. opencv.org $/ 2.4 /$ modules $/ \mathrm{ml} /$ doc/neural_networks.html

Partel V, Charan Kakarla S, Ampatzidis Y, 2019 . Development and evaluation of a low-cost and smart technology for precision weed management utilizing artificial intelligence. Comput. Electron. Agric. 157:339-50.

Paul CJM, Nehring R, 2005. Product diversification, production systems, and economic performance in U.S. agricultural production. J. Econom. 126:525-48.

Pérez-Ortiz M, Peña JM, Gutiérrez PA, Torres-Sánchez J, HervásMartínez C, López-Granados F, 2015. A semi-supervised system for weed mapping in sunflower crops using unmanned aerial vehicles and a crop row detection method. Appl. Soft Comput. J. 37:533-44.

Pérez-Ortiz M, Peña JM, Gutiérrez PA, Torres-Sánchez J, HervásMartínez C, López-Granados F, 2016. Selecting patterns and features for between- and within- crop-row weed mapping using UAV-imagery. Expert Syst. Appl. 47:85-94.

Peruzzi A, Martelloni L, Frasconi C, Fontanelli M, Pirchio M, Raffaelli M, 2017. Machines for non-chemical intra-row weed control in narrow and wide-row crops: A review. J. Agric. Eng. 48:57-70.

Radosevich SR, Holt JS, Ghersa C, Radosevich SR, 2007. Ecology of weeds and invasive plants : relationship to agriculture and natural resource management. Wiley-Interscience. Available from: https://books.google.it/books?hl=it\&lr=\&id= 2paeqsOV 2I8C\&oi $=$ fnd \&pg $=$ PR5\&dq=weeds + problem + agriculture \& ot $\mathrm{s}=\mathrm{mbgVprk7qL \& sig=Wc8YCyhWpPL7DfOBvRX91ZHXkv}$ $\mathrm{g} \# \mathrm{v}=$ onepage $\& \mathrm{q}=$ weeds problem agriculture $\& \mathrm{f}=$ false

Raghavan GSV, Alvo P, McKyes E, 1990. Soil compaction in agriculture: a view toward managing the problem. In: R. Lal, B.A. Stewart (Eds.), Advances in soil science, 11th edn. Springer, New York, NY, USA, pp 289-330.

Ricroch A, Chopra S, Fleischer SJ, 2014. Plant biotechnology: experience and future prospects. Plant Biotechnol. Exp. Futur. Prospect. 1-291.

Roberts RK, Hayes RMR, 1989. Decision criterion for profitable Johnsongrass (Sorghum halepense) management in soybeans (Glycine max). Weed Technol. 3:44-7.

Rumelhart ED, Hinton EG, Williams JR, 1986. Learning representations by back-propagation errors. Nature 323:533-6.

Santín-Montanyá I, Francisco de Andrés E, Zambrana E, Tenorio JL, 2015. The competitive ability of weed community with selected crucifer oilseed crops. In: A. Price, J. Kelton, L. Sarunaite (Eds.), Herbicides agronomic crops and weed biology. IntechOpen Limited, London, UK, pp 155-71.

Sartorato I, Berti A, Zanin G, 1996. Estimation of economic 
thresholds for weed control in soybean (Glycine max (L.) Merr.). Crop Prot. 15:63-8.

Schneider P, Roberts DA, Kyriakidis PC, 2008. A VARI-based relative greenness from MODIS data for computing the Fire Potential Index. Remote Sens. Environ. 112:1151-67.

Sherwani SI, Arif IA, Khan HA, 2015. Modes of action of different classes of herbicides. In: A. Price, J. Kelton, L. Sarunaite (Eds.), Herbicides, physiology of action and safety. IntechOpen Ltd., London, UK, pp 165-86.

Slaughter DC, Giles DK, Tauzer C, 1999. Precision offset spray system for roadway shoulder weed control. J. Transp. Eng. 125:364-71.

Soltani N, Dille AJ, Burke IC, Everman WJ, VanGessel MJ, Davis VM, Sikkema PH, 2016. Potential corn yield losses due to weeds in North America. Weed Technol. 30:979-84.

Sözen A, Arcaklioğlu E, Özalp M, Kanit EG, 2004. Use of artificial neural networks for mapping of solar potential in Turkey. Appl. Energy 77:273-86.

Story M, Congalton RG, 1986. Remote sensing brief accuracy assessment: a user's perspective. Photogramm. Eng. Remote Sensing 52:397-9.

Stroppiana D, Villa P, Sona G, Ronchetti G, Candiani G, Pepe M, Busetto L, Migliazzi M, Boschetti M, 2018. Early season weed mapping in rice crops using multi-spectral UAV data. Int. J. Remote Sens. 39:5432-52.

Takács-György K, 2008. Economic aspects of chemical reduction in farming - future role of precision farming. Food Econ. Acta Agric. Scand. Sect. C 5:114-22.

Thrall PH, Bever JD, Burdon JJ, 2010. Evolutionary change in agriculture: the past, present and future. Evol. Appl. 3:405-8.

Tiktak A, De Nie DS, Piñeros Garcet JD, Jones A, Vanclooster M, 2004. Assessment of the pesticide leaching risk at the PanEuropean level. The EuroPEARL approach. J. Hydrol.
289:222-38

Torres-Sánchez J, López-Granados F, De Castro AI, PeñaBarragán JM, 2013. Configuration and Specifications of an unmanned aerial vehicle (UAV) for early site specific weed management. PLoS One 8.

Turan NG, Mesci B, Ozgonenel O, 2011. The use of artificial neural networks (ANN) for modeling of adsorption of $\mathrm{Cu}$ (II) from industrial leachate by pumice. Chem. Eng. J. 171:1091-7.

Vats S, 2015. Herbicides: History, classification and genetic. In: E. Lichtfouse (Ed.), Sustainable agriculture reviews. Springer International Publishing, Berlin, Germany, pp. 153-92.

Weis M, Gutjahr C, Ayala VR, Gerhards R, Ritter C, Schölderle F, 2008. Precision farming for weed management: Techniques. Gesunde Pflanz. 60:171-81.

Wolf T, 2009. Best management practices for herbicide application technology. Prairie Soils Crop. J. 2:24-30.

Zanin G, Berti A, Sattin M, 1994. Estimation of economic thresholds for weed control in maize in Northern Italy. 5th EWRS Mediterr. pp 51-8 in Symp. 'Weed Control Sustain. Agric. Mediterr. Area'.

Zarco-Tejada PJ, Hubbard N, Loudjani P, 2014. Precision agriculture: an opportunity for Eu farmers- potential support with the cap 2014-2020. Eur. Parliam. Dir. Intern. Policies: 56. Available from: http://www.europarl.europa.eu/RegData/ etudes/note/join/2014/529049/IPOL-AGRI_NT(2014) 529049 EN.pdf

Zimdahl LR, 2007. Fundamentals of weed science, 3rd edn. Elsevier, Amsterdam, The Netherlands.

Zimdahl LR, 2018. Introduction to chemical weed control. In: N. Maragioglio, B.J. Fernandez (Eds.), Fundamentals of weed science, 5th edn. Academic Press, New York, NY, USA, pp 391-416. 